\title{
Lithos
}

December 2017, Volumes 294-295, Pages 356-361

http://dx.doi.org/10.1016/..lithos.2017.10.013

http://archimer.ifremer.fr/doc/00407/51832/

(c) 2017 Elsevier B.V. All rights reserved.

\section{Young Marquesas volcanism finally located}

\author{
Révillon Sidonie ${ }^{1,3,{ }^{*}}$, Guillou Hervé ${ }^{2}$, Maury René $C^{3}{ }^{3}$, Chauvel Catherine ${ }^{4}$, Aslanian Daniel ${ }^{5}$, \\ Pelleter Ewan ${ }^{5}$, Scao Vincent ${ }^{2}$, Loubrieu Benoit ${ }^{5}$, Patriat Martin ${ }^{5}$
}

${ }^{1}$ SEDISOR, IUEM, Place Nicolas Copernic, 29280, Plouzané, France

2 UMR 8212 LSCE/CEA-CNRS-UVSQ, 91118, Gif sur Yvette, France

${ }^{3}$ UMR 6538 Laboratoire Géosciences Océan, IUEM, Université de Bretagne Occidentale, 29280

Plouzané, France

${ }^{4}$ Université Grenoble Alpes, CNRS, ISTerre, 38000 Grenoble, France

${ }^{5}$ Unité de Recherche Géosciences marines, Ifremer-, CB, 29280 Plouzané, France

* Corresponding author : Sidonie Révillon, email address : sidonie.revillon@sedisor.eu

\begin{abstract}
:
The Marquesas Island chain in Polynesia is quite unusual because the alignment of the islands on the Pacific oceanic plate $\left(\mathrm{N} 40^{\circ} \mathrm{W}\right)$ does not follow the plate motion in the region $\left(\mathrm{N} 65^{\circ} \mathrm{W}\right)$. The exact location of the active hotspot is unknown but has been predicted to underlie the Marquesas Fracture Zone Ridge. Nevertheless, no concrete evidence exists. Here, we document the occurrence on this ridge of fresh tephrites dated at $\sim 92 \mathrm{ka}$ by the 40Ar-39Ar method. The lavas dredged on a small seamount have trace element contents and $\mathrm{Sr}, \mathrm{Nd}, \mathrm{Pb}$ isotopic compositions typical of the southwest Marquesas Islands, the Fatu Hiva group. This discovery demonstrates that the Marquesas plume is still active and it puts new constraints on its present location. It also supports McNutt et al.'s (1989) interpretation of the Marquesas Fracture Zone Ridge as a very young volcanic construction underlain by a hotspot. We suggest that the present location of the Marquesas plume is under the ridge, at its intersection with the isotopic divide known along the Marquesas chain. We attribute the presence of young volcanic products $190 \mathrm{~km}$ southwest of this location to preferential magma flow along the Marquesas Fracture lithospheric weakness zone. We also suggest that the puzzling general direction of the archipelago is the consequence of a persistent low magma flux over the past $5 \mathrm{Ma}$ that could only find its way to the surface through multiple weak zones in the Pacific plate.
\end{abstract}




\section{Highlights}

- Fresh tephrites dated at $~ 92$ ka by the ${ }^{40} \mathrm{Ar}-{ }^{39} \mathrm{Ar}$ method have been dredged from the Marquesas Fracture Zone Ridge. They represent the youngest volcanic rocks known from the Marquesas linear chain. Their trace elements element contents and $\mathrm{Sr}, \mathrm{Nd}, \mathrm{Pb}$ isotopic compositions are typical of the southwest Marquesas Islands, the Fatu Hiva group. This discovery demonstrates that the Marquesas plume is still active and it puts new constraints on its present location. We suggest that the present location of the Marquesas plume is under the ridge, at its intersection with the isotopic divide known along the Marquesas chain.

Keywords: submarine volcanism, 40Ar-39Ar ages, geochemistry, plume, Marquesas, French Polynesia 


\section{Introduction}

Polynesian volcanic chains display younger ages towards their southeast end (Duncan and McDougall, 1976) and active or very young seamounts at their SE tip. The latter mark the present-day location of the underlying hotspot, e.g. the Macdonald seamount for the AustralCook chain (Binard et al., 1991; Maury et al., 2013), the Mehetia islet and adjacent seamounts for the Society (Binard et al., 1991), and the Pitcairn seamounts for the Pitcairn-Gambier chain (Binard et al., 1992). Along the Marquesas chain, the ages of the islands decrease SE from $~ 5.5$ Ma at Eiao to 1.1 Ma at Fatu Hiva (Duncan and McDougall, 1974; Guillou et al., 2014), and 
the youngest ages have been reported for a seamount located $50 \mathrm{~km}$ SE of Fatu Hiva (0.35-0.76 Ma, DH 12, Fig. 1; Desonie et al., 1993). The situation is therefore less clear because there was, so far, no concrete evidence of young or active volcanism, and of the present location of the Marquesas hotspot.

The Marquesas Fracture Zone lies 100 km south of Fatu Hiva. It is lined by an unusual 350 $\mathrm{km}$ long topographic ridge (20 km wide and $1.5 \mathrm{~km}$ high) called the Marquesas Fracture Zone Ridge (Fig. 1). This structure was interpreted by McNutt et al. (1989) as a young volcanic structure marking the present-day location of the Marquesas hotspot. Although this interpretation is generally accepted (Brousse et al., 1990; Desonie et al., 1993; Legendre et al., 2006; Guillou et al., 2014), it was not supported by any sampling of very young volcanic rocks from the ridge. Here we present new geochemical and geochronological data obtained on fresh lavas dredged on the ridge, we compare their geochemical compositions to those of older products of the Marquesas hotspot and we constrain their age.

\section{Sampling and results}

The studied samples were dredged in September 2012 during the POLYPLAC cruise of N.O. L'Atalante on the north flank of the Marquesas Fracture Zone ridge (138 $6^{\prime} \mathrm{W}, 11^{\circ} 20^{\prime} \mathrm{S}$; Fig. 1). The PLP-DR-01 profile was dredged between -2900 and $-2640 \mathrm{~m}$ on two small seamounts (see Fig. S1). It recovered very fresh to variably altered vesicle-rich lavas, displaying Loss On Ignition (LOI) values ranging from -0.06 to $1.68 \mathrm{wt} \%$. The freshest samples (PLP-DR-01-04, PLP-DR-01-05, PLP-DR-01-06 with low LOI at 0.10, 1.17 and -0.06 wt\%, Table S1) were selected for geochemical studies and ${ }^{40} \mathrm{Ar} /{ }^{39} \mathrm{Ar}$ dating (see Online Supplementary Information for analytical methods). They are intermediate silica-undersaturated alkaline rocks $\left(\mathrm{SiO}_{2} \sim 45 \mathrm{wt} \%\right.$, $\mathrm{TiO}_{2} \sim 3 \mathrm{wt} \%, \mathrm{MgO} \sim 4 \mathrm{wt} \%$, Table S1) that plot within the field of tephrites in a total alkalisilica plot (not shown). They contain 20 to 35 volume $\%$ of millimeter-size void vesicles, and 
display a subaphyric microlitic texture, with $2-5$ volume $\%$ microphenocrysts of skeletal plagioclase up to $0.3 \mathrm{~mm}$ long, that range in composition from labradorite to andesine $\left(\mathrm{An}_{62-40}\right)$. These phenocrysts are set in a groundmass containing andesine laths, diopside ( $\mathrm{Wo}_{51-44}$ ), titanomagnetite $\left(\mathrm{TiO}_{2}=19-14 \mathrm{wt} \%\right)$, rare olivine $\left(\mathrm{Fo}_{75-73}\right)$ grains, interstitial alkali feldspar patches (anorthoclase to soda sanidine, $\mathrm{Or}_{24-52}$ ) and residual silica-undersaturated glass of phonotephritic composition $\left(\mathrm{SiO}_{2} \sim 54 \mathrm{wt} \%, \mathrm{Na}_{2} \mathrm{O} \sim 5.6 \mathrm{wt} \%, \mathrm{~K}_{2} \mathrm{O} \sim 3.4 \mathrm{wt} \%\right)$. Post-magmatic minerals have not been identified in these samples.

Trace element data (Table S2) show that they have low contents in compatible elements (Co $~ 25$ ppm, Ni $<10$ ppm, $\mathrm{Cr}<15 \mathrm{ppm}$ ) consistent with their intermediate (tephritic) composition. Their incompatible element patterns (Fig. 2) display high contents in $\mathrm{Nb}, \mathrm{Ta}$, La and $\mathrm{Ce}$, strong negative anomalies in $\mathrm{Pb}$ and relative depletion in $\mathrm{Cs}, \mathrm{Rb}$ and $\mathrm{Ba}$. These features are typical of Marquesas lavas (Dupuy et al., 1987; Chauvel et al., 2012), and resemble those of mafic lavas from the neighboring islands of Fatu Hiva, Tahuata and Motane (Fig. 2).

$\mathrm{Sr}, \mathrm{Nd}, \mathrm{Pb}$ isotopic data (Table S3) are similar in the three analyzed samples and plot within the range of Marquesas lavas (Dupuy et al., 1987; Woodhead, 1992; Chauvel et al., 2012). Chauvel et al. (2012) distinguished two isotopic groups among Marquesas Islands, one with elevated Nd isotopes at a given ${ }^{206} \mathrm{~Pb} /{ }^{204} \mathrm{~Pb}$ (the northern Ua Huka group) and one with lower $\mathrm{Nd}$ isotopes (the southern Fatu Hiva group). As shown in Figure 3, the three PLP-DR-01 samples plot consistently within the Fatu Hiva group, in agreement with their geographical location (Fig. 1).

The groundmass separated from the two freshest samples (PLP DR-01-04 and PLP DR-01-06) was dated by the ${ }^{40} \mathrm{Ar} /{ }^{39} \mathrm{Ar}$ method. Step-heating experiments achieved on samples PLP DR-0106 and PLP DR-01-04 yield concordant age spectra with 100\% of the gas defining the age plateau (Table 1, Table S4). Plateau ages are similar within errors and extremely young for both samples: 90.6 \pm 5.7 ka (sample PLP DR-01-06) and 93.5 \pm 8.3 ka (sample PLP DR-01-04) (Fig. 4). 


\section{Discussion}

The Marquesas archipelago is unusual in many aspects (Guille et al., 2002): (a) it is very wide (up to $100 \mathrm{~km}$ ) (Fig. 1) compared to other Polynesian chains (Society, Pitcairn-Gambier and Austral-Cook); (b) its overall $\mathrm{N} 40^{\circ} \mathrm{W}$ trend is clearly oblique to the current $\mathrm{N} 65^{\circ} \mathrm{W}$ motion of the Pacific plate; (c) it lies over an exceptionally thick crust (up to 15-20 km, Caress et al., 1995); and (d) active volcanism has not yet been found at its SE tip. However, considering the $10.5 \mathrm{~cm} /$ year local motion of the Pacific plate towards the NW (McDougall and Duncan, 1980; Legendre et al., 2006; Wessel and Kroenke, 2007) and the overall age range of the Marquesas Islands, the Marquesas plume could be presently active beneath the Marquesas fracture zone ridge (McNutt et al., 1989; see Fig. 1).

The Marquesas fracture zone ridge presents several characteristics that are very unusual for ridges associated to oceanic transform faults. While its length $(350 \mathrm{~km})$ is quite ordinary, its width $(\sim 20 \mathrm{~km})$ and height $(1.5 \mathrm{~km})$ are very unusual (Pautot and Dupont, 1974; McNutt et al., 1989). This led McNutt et al. (1989) to suggest that the MFZ ridge was a young volcanic structure marking the present-day location of the Marquesas hotspot but unfortunately, they could not collect any young volcanics to support their hypothesis.

The very young age $(\sim 92 \mathrm{ka})$ of the two fresh samples collected during the N.O L'Atalante cruise provides the first unambiguous evidence that very young volcanism occurred along the MFZ ridge. It also raises new questions about the geometry of the plume feeding the Marquesas chain because the sampling site is away from the central sector of the ridge, at its SW tip and in the general continuity of the $\mathrm{N} 40^{\circ} \mathrm{W}$ trend of the archipelago (Figs. 1 and 5).

Using the geochemical and isotopic data obtained on the dredged samples helps answering such questions. Chauvel et al. (2012) demonstrated that the Marquesas chain was characterized by the juxtaposition of two rows of islands (labelled the Ua Huka group and the Fatu Hiva group 
respectively, see Figure 1) with distinct isotopic compositions (Fig. 3). They suggested that these two isotopic stripes originated from partial melting of two adjacent filaments contained in "plumelets" that came from a large dome structure located deep in the Polynesian mantle. The $\mathrm{N} 65^{\circ} \mathrm{W}$ geographical boundary between the two geochemical stripes, shown by the white line in Figure 1, separates the northeastern group of islands (the Ua Huka group) from the southwestern one (the Fatu Hiva group). As shown in Figure 3, the PLP-DR-01 samples plot within the range of values of the Fatu Hiva group, as expected from their geographical position $\sim 190 \mathrm{~km} \mathrm{SW} \mathrm{of}$ the boundary (Fig. 1). It thus confirms that the distinction established from past volcanism data is still valid at present.

In Figure 5, we explore the age versus distance relationship along the Marquesas chain depending on the chosen reference frame to locate the present Marquesas plume. Panel (a) presents a sketch of the Marquesas Archipelago and Marquesas fracture zone ridge geography, as well as the location of the very young volcanic activity and the three possible scenarios (A, B and C) that we use to calculate distances. The best scenario should be the one in which the agedistance fit for the oldest known eruption of each island corresponds to the general Pacific plate motion speed $(10.5 \mathrm{~cm} /$ year), keeping in mind that the available ages obtained from surface samples are probably significantly younger than those of the initiation of submarine volcanism at the same location.

Panel (b) shows essentially the information as published in Guillou et al. (2014) where ages are plotted relative to the island's distance to the ridge (scenario A in Fig. 5b). It evidences a rather weak age-distance correlation since only two islands, Ua Pou and Fatu Hiva, fall on the reference line. This suggests that the choice of the Marquesas Fracture Zone ridge as reference to calculate distances is not the optimal probably because of the obliquity between the ridge and the Pacific plate motion. The distances calculated for the oldest islands (Eiao, Nuku Hiva and Ua Huka) are most likely too large and they fall significantly below the Pacific plate motion line in Figure 5b. 
For younger islands located closer to the fracture zone ridge, the bias is smaller. Using scenario A, we calculated an average Pacific plate motion that would fit the oldest ages of most islands (dashed line). The calculated plate velocity is then $12.7 \mathrm{~cm} / \mathrm{year}$, a value that is clearly too high compared to published estimates (Wessel and Kroenke, 2007). In Panel (c), we use the PLP-DR01 location as reference to calculate distances (scenario B). Doing so, almost all islands fall above the Pacific plate motion line and the older the island is, the larger the deviation is. The best fit (dashed line) provides a plate velocity of $7.3 \mathrm{~cm} /$ year that is clearly too low. In contrast, if, as illustrated in panel (d), we use the isotopic divide line defined between the northern Ua Huka group and the southern Fatu Hiva group as the reference frame (scenario C), the general age progression follows more closely the regional Pacific plate speed, although young lavas from PLP-DR-01 and DH 12 plot away from the main trend. This in turn suggests that the Marquesas plume would be located at the level of the present-day intersection between the Marquesas Fracture Zone ridge and the isotopic divide line. The (relatively) remote location of PLP-DR-01 site with respect to this intersection (Figs 1 and 5) might be a consequence of preferential magma flow along the MFZ major lithospheric weakness zone, as previously proposed by McNutt et al. (1989).

It could be argued that the location of the samples along the $\mathrm{N} 40^{\circ} \mathrm{W}$ general direction of the archipelago could be interpreted in terms of non-stationary magma sources, unrelated to a deep mantle plume. In that case, the distance between old islands and present location of volcanic activity would indeed be unrelated to the Pacific plate motion. However, such scenario would have difficulties to explain the persistent isotopic differences between the northeastern and southwestern groups of islands.

The Marquesas plume is characterized by relative low magma production per unit of time ( $7,000 \mathrm{~km}^{3} / \mathrm{Ma}$; Chauvel et al., 2012) and the erupted volcanic products include a large proportion of low degree melts as well as a remarkable volume of differentiated liquids such as phonolites 
and trachytes (Legendre et al., 2005a, 2005b). These low volumes confer to it a "weak" character that could explain the "imperfect" alignment of islands when compared with a steady deep plume such as Hawaii. It could also enhance the control of major crustal weakness zones, such as the Marquesas Fracture Zone, on the geographical surface expression of the plume. Indeed, most Marquesas volcanic islands and seamounts also form linear arrays subparallel to the Marquesas Ridge and all clearly oblique to the Pacific plate motion (Fig. 1). This is the case for the oldest group of islands that includes Eiao, Hatutu and Goguel Bk, and for the group that includes Fatu Hiva, Motu Nao and other unsampled seamounts further South (Fig. 1). It could also be the case for the presently uninvestigated chain of seamounts that is located parallel to the Marquesas fracture zone ridge but $\sim 50 \mathrm{~km}$ north. In addition, the southerne halves of Nuku Hiva and Ua Huka collapsed along faults subparallel to the MFZ (Merle et al., 2006; Maury et al., 2014) and the four coalescent volcanoes of Hiva Oa are aligned in a similar direction (Guillou et al., 2014). These features are consistent with the hypothesis that the Pacific oceanic plate underlying the archipelago includes multiple faults or weakness zones parallel to its major fracture zones (McNutt et al., 1989; Brousse et al., 1990; Merle et al., 2006). Magmas originating from the "weak" Marquesas plume (McNutt et al., 1989; Chauvel et al., 2012) would mostly reach the surface periodically and build islands or seamounts when channelled along such lithospheric fractures.

\section{Conclusions}

The $\sim 92 \mathrm{ka}$ age of two samples from Dredge PLP DR-01 provides the first direct evidence that very young magmas erupted along the Marquesas fracture zone ridge. This observation supports the early conclusion of McNutt et al. (1989) that this unusual ridge is linked to the present position of the Marquesas hotspot. The Dredge PLP DR-01 samples also have geochemical and 
isotopic characteristics similar to the Fatu Hiva group (Chauvel et al., 2012). These features are consistent with the location of the dredge $190 \mathrm{~km} \mathrm{SW}$ of the potential boundary between the two isotopic domains along the archipelago. Even if recent volcanism occurred there, we suggest that the Marquesas plume is presently located under the ridge but at its intersection with the isotopic divide because this hypothesis provides the best fit for the age-distance relationship and is also consistent with the available geochemical data. We propose that the existence of weakness zones within the Pacific crust could explain the spread of the surface expression of the plume over relatively large areas and the overall direction of the archipelago which differs from that of the Pacific plate motion.

\section{Acknowledgements}

$\mathrm{BL}$ and MP thank the Atalante crew for all the great work performed during the POLYPLAC 2012 cruise in September 2012, and Walter R. Roest, scientific leader of the EXTRAPLAC project, a French national program that funded the cruise. HG, SR and RM thank J.-L. Joron, J. Etoubleau, S. Chéron and J. Langlade for their help during the analytical work. Brian Jicha provided helpful comments on an early version of this manuscript that was improved following the constructive reviews of Takeshi Hanyu and Anthony Koppers.

\section{References}

Binard, N., Hékinian, R., Cheminée, J.L., Searle, R.C., Stoffers, P., 1991. Morphological and structural studies of the Society and Austral hot spot regions in the South Pacific. Tectonophysics 186, 293-312. 
Binard, N., Hékinian, R., Stoffers, P., 1992. Morphostructural study and type of volcanism over the Pitcairn hot spot in the South Pacific. Tectonophysics 206, 245-264.

Brousse, R., Barsczus, H. G., Bellon, H., Cantagrel, J.-M., Diraison, C., Guillou, H., Léotot, C., 1990. Les Marquises (Polynésie française): volcanologie, géochronologie, discussion d'un modèle de point chaud. Bulletin de la Société Géologique de France (8), 6, 933-949.

Caress, D. W., McNutt, M. K., Detrick, R. S., Mutter, J. C., 1995. Seismic imaging of hotspotrelated underplating beneath the Marquesas Islands. Nature 373, 600-603.

Chauvel, C., Maury, R.C., Blais, S., Lewin, E., Guillou, H., Guille, G., Rossi, P., Gutscher, M-A., 2012. The size of plume heterogeneities constrained by Marquesas isotopic stripes. Geochemistry Geophysics Geosystems 13, Q07005, doi: 10.129/2012GC004123.

Desonie, D. L., Duncan, R. A., Nielsen, R. N., Natland, J. H., 1993. Temporal and geochemical variability of volcanic products of the Marquesas hotspot. Journal of Geophysical Research $98, \mathrm{n}^{\circ} \mathrm{B} 10,17649-17665$

Duncan, R. A., McDougall, I., 1974. Migration of volcanism with time in the Marquesas islands, French Polynesia. Earth and Planetary Science Letters 21, 414-420.

Duncan, R.A., McDougall, I., 1976. Linear volcanism in French Polynesia. Journal of Volcanology and Geothermal Research 1, 197-227.

Dupuy, C., Vidal, P., Barsczus, H.G., Chauvel, C., 1987. Origin of basalts from the Marquesas archipelago (South Central Pacific Ocean): isotope and trace element constraints. Earth and Planetary Science Letters 82, 145-152.

Guille, G., Legendre, C., Maury, R., Caroff, M., Munschy, M., Blais, S., Chauvel, C., Cotten, J., Guillou, H., 2002. Les Marquises (Polynésie française): un archipel intraocéanique atypique. Géologie de la France 2, 5-35. 
Guillou, H., Maury, R. C., Guille, G., Chauvel, C., Rossi, P., Pallares, C., Legendre, C., Blais, S., Liorzou, C., Deroussi, S., 2014. Volcanic successions in Marquesas eruptive centers: a departure from the Hawaiian model. Journal of Volcanology and Geothermal Research 276, 173-188.

Legendre, C., Maury, R.C., Blais, S., Guillou, H., Cotten, J., 2006. Atypical hotspot chains: evidence for a secondary melting zone below the Marquesas (French Polynesia). Terra Nova $18,210-216$.

Legendre, C., Maury, R.C., Caroff, M., Guillou, H., Cotten, J., Chauvel, C., Bollinger, C., Hémond, C., Guille, G., Blais, S., Rossi, P., Savanier, D., 2005a. Origin of exceptionally abundant phonolites on Ua Pou island (Marquesas, French Polynesia): partial melting of basanites followed by crustal contamination. Journal of Petrology 46, 1925-1962.

Legendre, C., Maury, R.C., Savanier, D., Cotten, J., Chauvel, C., Hémond, C., Bollinger, C., Guille, G., Blais, S., Rossi, P., 2005b. The origin of intermediate and evolved lavas in the Marquesas archipelago: an example from Nuku Hiva island (French Polynesia). Journal of Volcanology and Geothermal Research 143, 293-317.

Maury, R. C., Guille, G., Guillou, H., Chauvel, C., Rossi P., Pallares, C., Legendre C., 2013. Temporal evolution of a Polynesian hotspot: New evidence from Raivavae (Austral Islands, South Pacific Ocean). Bulletin de la Société géologique de France 184, 385-395.

Maury, R. C., Guille, G., Guillou, H., Chauvel, C., Legendre, C., Rossi, P., Blais, S., Pallares, C., Deroussi, S., Marabal, A.-M., 2014. Géologie des Marquises: des volcans boucliers intraocéaniques effondrés issus d'un point chaud atypique. Géologie de la France 1, 111- 135.

McDonough, W.F., and Sun, S.-S., 1995. Composition of the Earth. Chemical Geology 120, 223253. 
McDougall, I., Duncan, R.A., 1980. Linear volcanic chains: recording plate motions? Tectonophysics 63, 275-295.

McNutt, M.-K., Fischer, K., Kruse, S., Natland, J., 1989. The origin of the Marquesas fracture zone ridge and its implications for the nature of hotspots. Earth and Planetary Science Letters 91, 381-393.

Merle, O., Barde-Cabusson, S., Maury, R.C., Legendre, C., Guille, G., Blais, S., 2006. Volcano core collapse triggered by regional faulting. Journal of Volcanology and Geothermal Research $158,207-220$.

Pautot, G., Dupont, J., 1974. La zone de fracture des Marquises. Comptes Rendus de l'Académie des Sciences Paris, série D, 279, 1519-1521.

Sharp, W.D., Renne, P.R., 2005. The ${ }^{40} \mathrm{Ar} /{ }^{39} \mathrm{Ar}$ dating of core recovered by the Hawaii scientific drilling project (phase 2), Hilo, Hawaii. Geochemistry Geophysics Geosystems 6, Q04G17, doi: 10.1029/2004GC000846.

Smith, W.H.F., Sandwell, D.T., 1997. Global seafloor topography from satellite altimetry and ship depth soundings. Science 277, 1956-1962.

Wessel, P., Kroenke, L.W., 2007. Reconciling late Neogene Pacific absolute and relative plate motion changes. Geochemistry Geophysics Geosystems 8, Q08001, doi: 10.129/2007GC001636.

Woodhead, J. D., 1992. Temporal geochemical evolution in oceanic intra-plate volcanics: a case study from the Marquesas (French Polynesia) and comparison with other hotspots. Contributions to Mineralogy and Petrology 111, 458-467. 


\section{Figure captions}

Figure 1. Bathymetric map of Marquesas Islands, drawn from the global altimetry data set of Smith and Sandwell (1997) and showing the location of Dredge PLP-DR-01 (red star). The main trend of the Marquesas chain is $\mathrm{N} 40^{\circ} \mathrm{W}$. Current Pacific plate motion is $10.5 \mathrm{~cm} / \mathrm{yr}$ at $\mathrm{N} 65^{\circ} \mathrm{W}$, corresponding to the solid white line that separates the two isotopic groups of islands identified in Figure 2 and Figure 3 (Ua Huka and Fatu Hiva groups) according to Chauvel et al. (2012). The names of the islands are in blue (northeastern group) or red (southwestern group) depending on their isotopic features. MFZ: Marquesas Fracture Zone.

Figure 2. Incompatible multi-element patterns of Dredge PLP-DR-01 samples compared to those of typical mafic lavas from the neighboring islands of Fatu Hiva, Tahata and Motane (taken from Chauvel et al., 2012). Normalization to the Primitive Mantle according to McDonough and Sun (1995).

Figure 3. ${ }^{87} \mathrm{Sr} /{ }^{86} \mathrm{Sr}$ versus ${ }^{206} \mathrm{~Pb} /{ }^{204} \mathrm{~Pb}(\mathrm{a}),{ }^{143} \mathrm{Nd} /{ }^{144} \mathrm{Nd}$ versus ${ }^{206} \mathrm{~Pb} /{ }^{204} \mathrm{~Pb}$ (b) and ${ }^{87} \mathrm{Sr} /{ }^{86} \mathrm{Sr}$ versus ${ }^{143} \mathrm{Nd} /{ }^{144} \mathrm{Nd}$ (c) isotopic diagrams for Marquesas lavas, adapted from Chauvel et al. (2012), showing the differences between the northeastern islands (Ua Huka group, in shades of blue) and the southwestern ones (Fatu Hiva group, in shades of red). The samples from Dredge PLP-DR01 are shown as red stars.

Figure 4. Age spectra (left) and isochrons (right) for two samples from PLP-DR-01. Errors are given at the 2 sigma level. 


\section{Figure 5.}

Position of PLP-DR-01 samples (red star) in age versus distance plots for the Marquesas Islands along the Pacific lithosphere motion. Panel (a) shows the location of the various islands of the Marquesas chain and that of the Marquesas Fracture Zone Ridge. It also explains how distances plotted in panels b, c and d were calculated. In panel (b) the Marquesas hotspot is considered as a linear structure underlying the Marquesas Fracture zone (Scenario A), as assumed by previous authors (Legendre et al., 2006; Guillou et al., 2014). In panel (c), it is considered as a linear structure perpendicular to the $\mathrm{N} 65^{\circ} \mathrm{W}$ trend and going through the location of dredge PLP-DR-01 (Scenario B). Finally, in panel (d), the reference is taken as the intersection of the isotopic divide line that follows the plate motion direction (Chauvel et al., 2012) and the Marquesas Fracture Zone (Scenario C). Unspiked K-Ar ages of islands are from Guillou et al. (2014). The northeastern islands (Ua Huka group) are shown in blue and the southwestern ones (Fatu Hiva group) in red as in Figures 1 and 3. MFZ Ridge: Marquesas Fracture Zone Ridge. The age range on Fatu Hiva island (1.81-1.11 Ma) has been extended to include the 0.84 (DH 17-1) and 0.74 (DH 18-26) Ma ages measured on its submarine slopes (Desonie et al., 1993). Besides PLP-DR01, the only ages younger than 0.5 Ma in the Marquesas are those of dredged mugearites from DH 12 seamount (Desonie et al., 1993). The origin of rejuvenated volcanism in Ua Huka (1.15$0.76 \mathrm{Ma}$ ) is attributed to the existence of a secondary melting zone beneath this island (Legendre et al., 2006).

\section{Table caption}

Table 1. Summary of ${ }^{40} \mathrm{Ar} /{ }^{39} \mathrm{Ar}$ data from incremental heating experiments. Analytical methods 
explained in Online Supplementary Material and detailed results shown in Figure 4 and Table S4. 


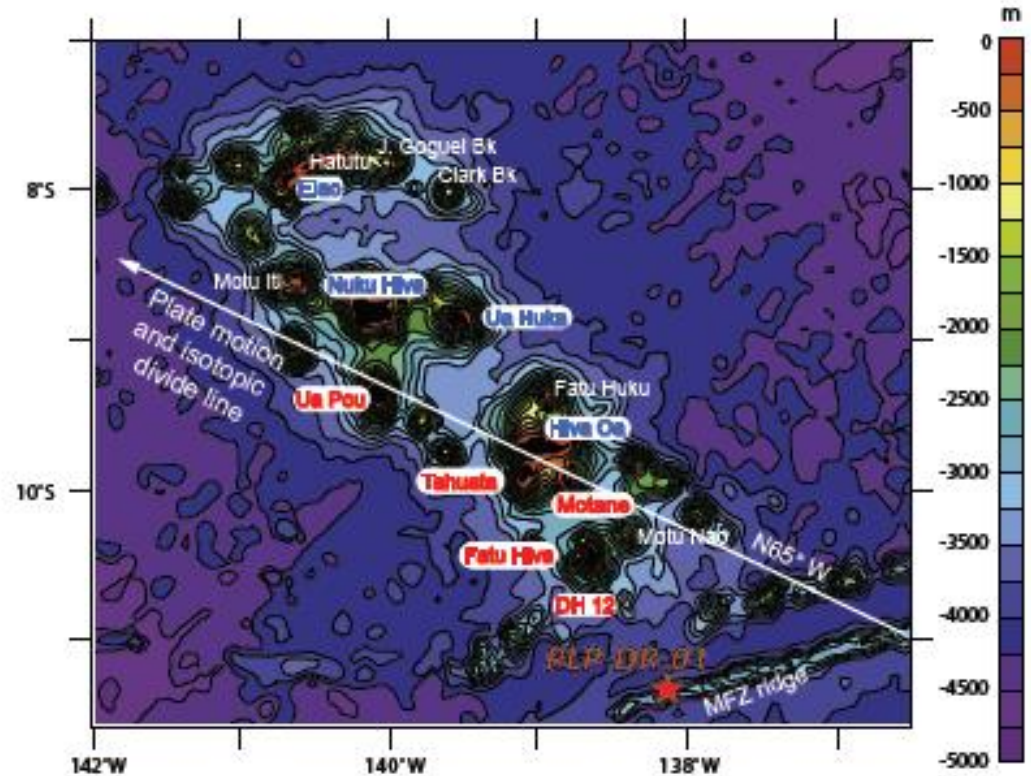

Revillon et al., Figure 1 


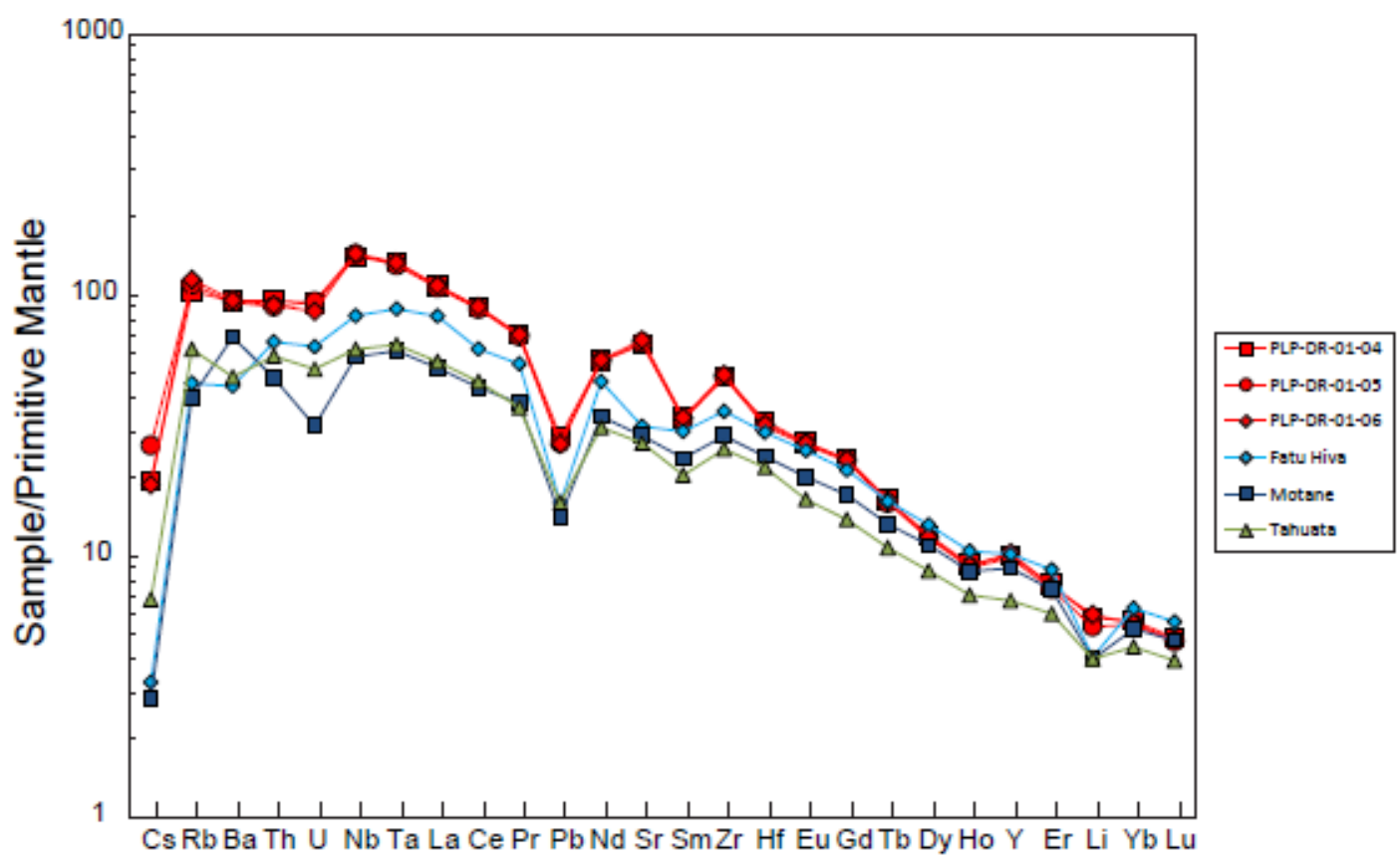

Revillon et al., Figure 2 

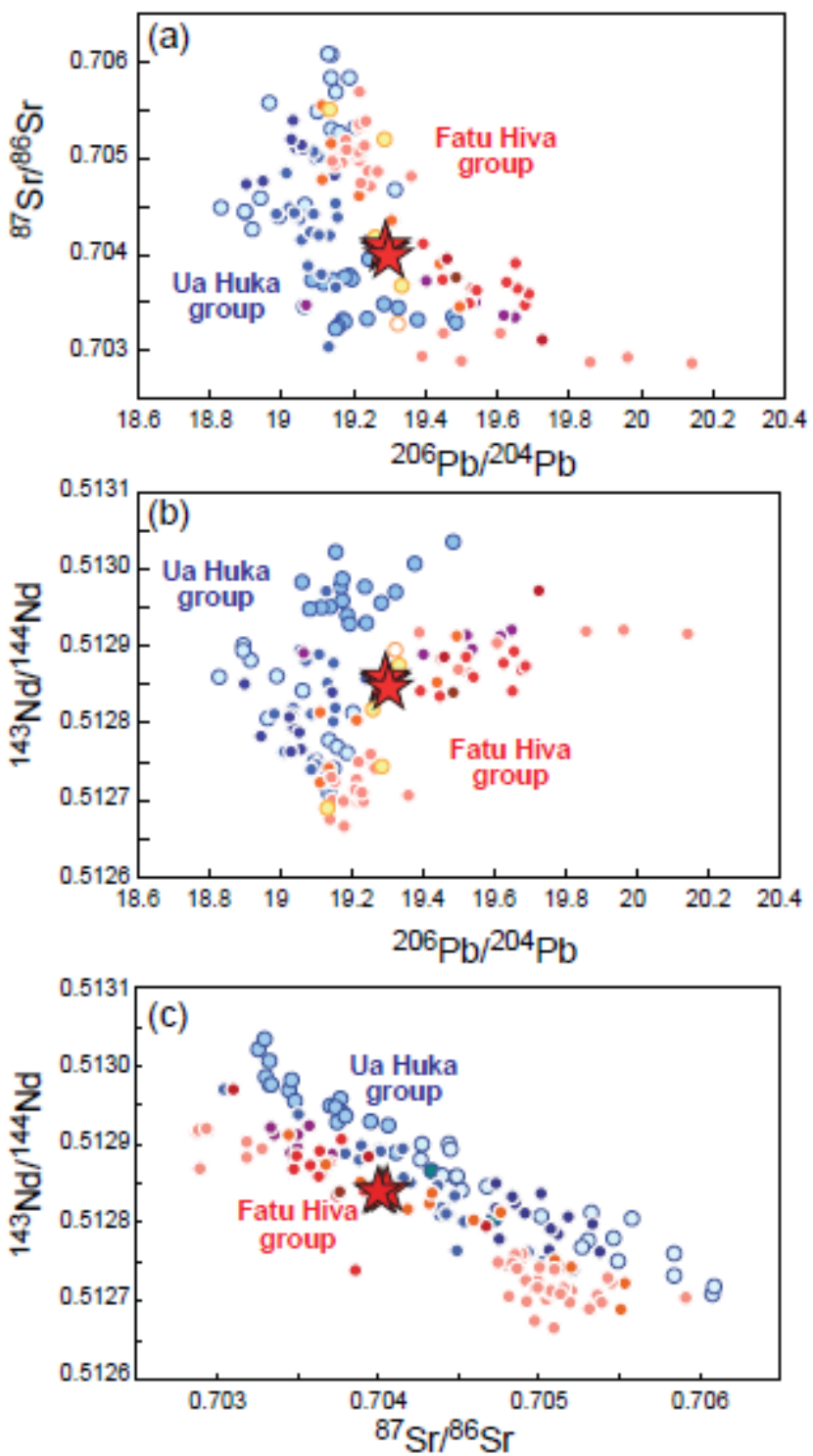

Revillon et al., Figure 3 

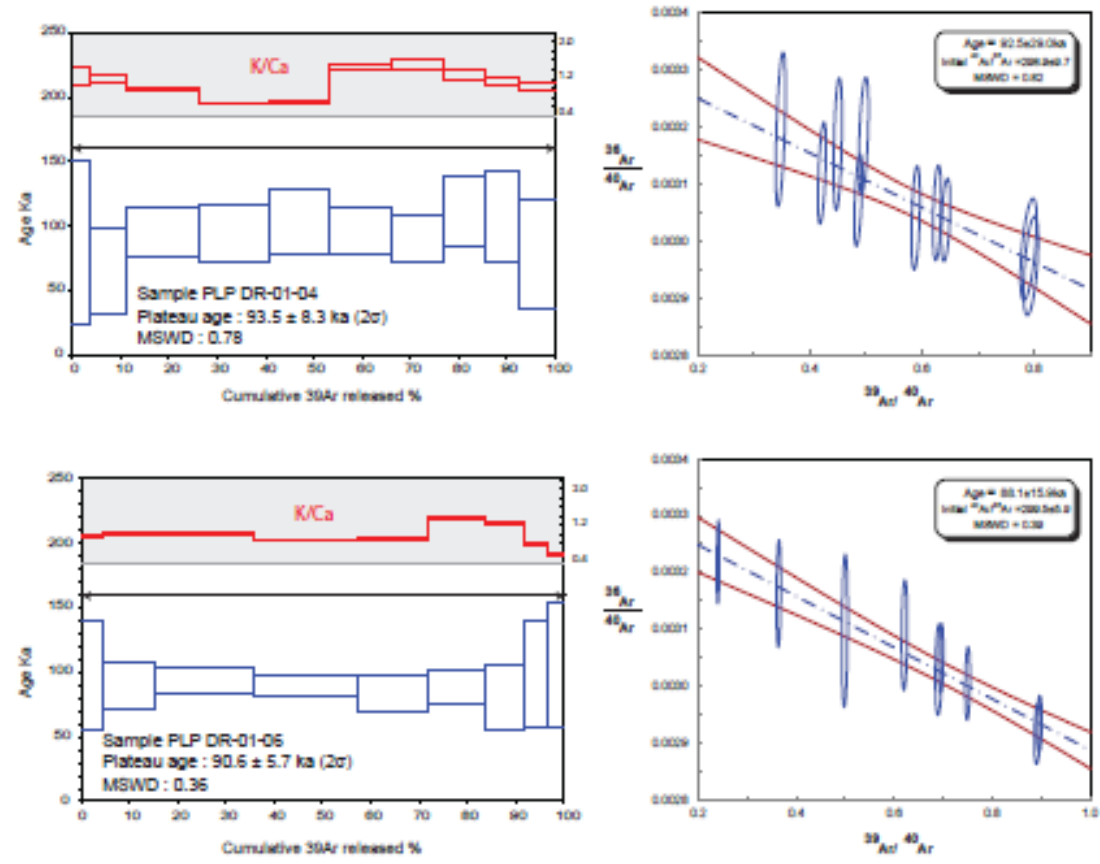

Revillon et al., Figure 4 
Revillon et al., Figure $\mathbf{5}$

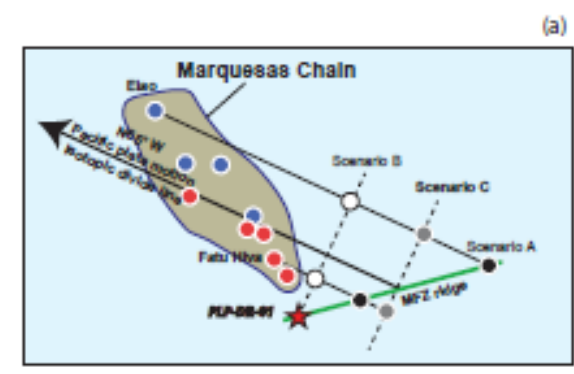

(a)
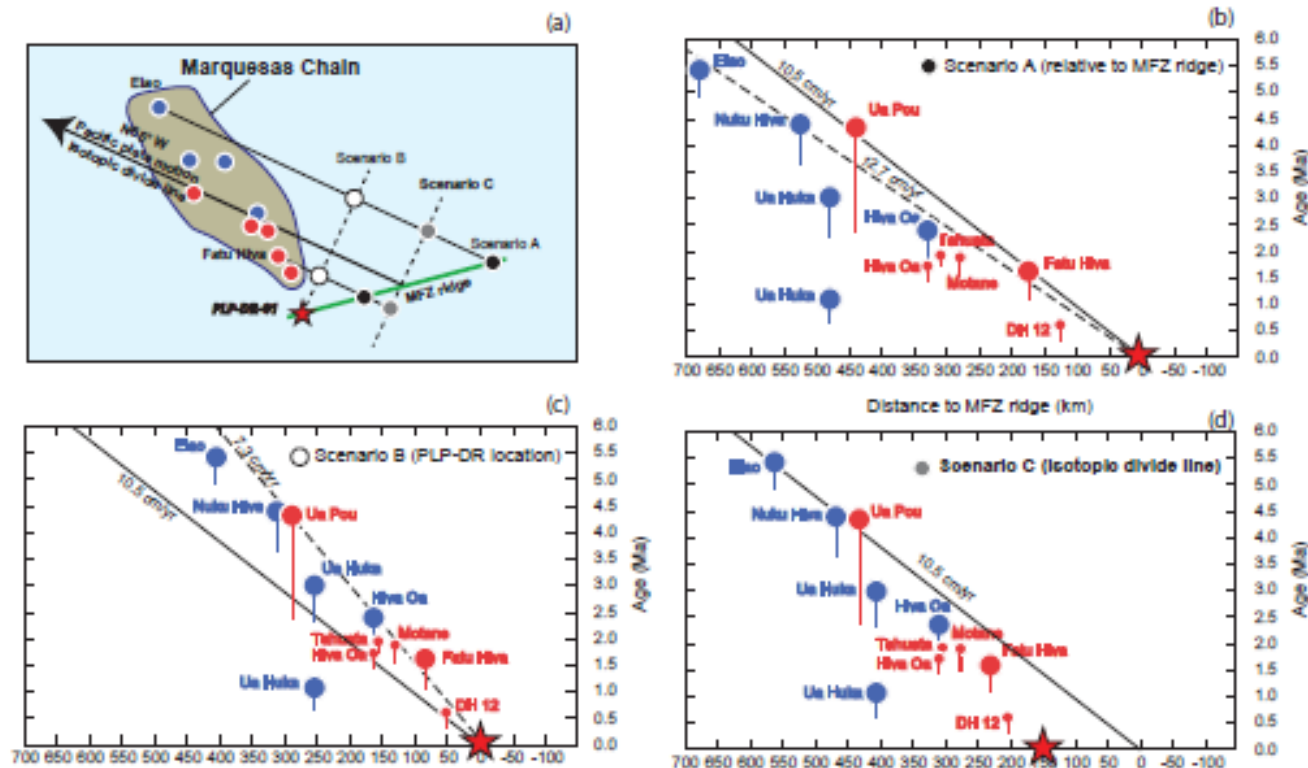

Distance to hotspot $(\mathrm{km})$

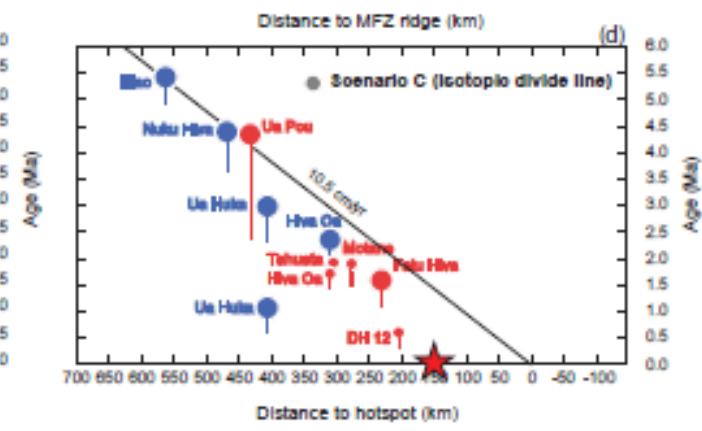


Table 1: Summary of 40Ar/ 39Ar data from incremental heating experiments

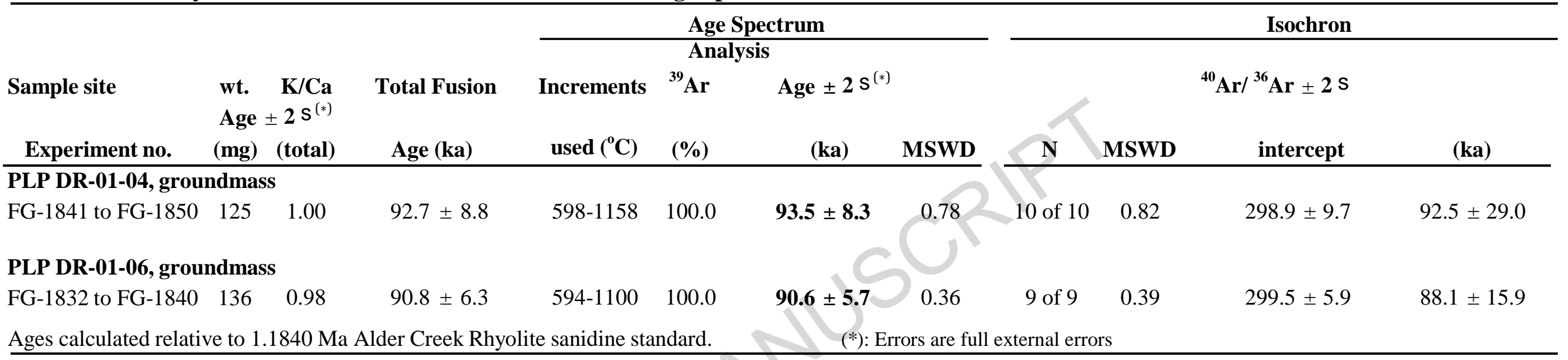

